\title{
Key Drivers of Digital Transformation in Greek Businesses: Strategy vs. Technology
}

\author{
Maria Karekla ${ }^{1}$, Yannis Pollalis², Michail Angelopoulos ${ }^{3}$
}

Submitted: 3.11.2020. Accepted: 9.03.2021

\section{Abstract}

Purpose: This article aims to assess strategy and technology as key drivers of Greek businesses' digital transformation and compare the results to those of international studies and sources.

Methodology: A research was conducted on 124 Greek businesses from different sectors and industries with the use of an anonymous questionnaire from December 2019 to January 2020. Greek businesses were categorized as early, developing, and maturing according to their perceptions about the level of their digital maturity, and differences were identified. The results were finally compared to an international relevant survey.

Findings: Several differences were located among the Greek businesses of the three digital maturity categories as formulated after their self-evaluation, and evolution has been identified on their perceptions about their digital strategy, its existence, objectives, and structure, which can be seen developing and expanding from the lowest to the highest levels of digital maturity.

Originality: The findings can be useful in creating an initial picture of the perceptions and practices applied by Greek businesses to their use of digital technologies. They can also become a measure of comparison for the self-evaluation of Greek businesses in their efforts to digitally transform.

Keywords: digital transformation, digital strategy, digital technology, digital maturity, digital technology management, businesses, Greece.

JEL: 033, 032, 031, M15

\footnotetext{
Hellenic Open University Patras, Western Greece.

University of Piraeus - Economics Pireas Greece, e-mail: yannis@unipi.gr.

Corresponding author, University of Piraeus - Economics Karaoli \& Dimitriou 80, Pireas 18534 Greece, e-mail: mangelopoulos66@gmail. com; https://orcid.org/0000-0002-5918-0806.
} 


\section{Introduction}

Digital transformation is the goal of almost every company. New digital technologies such as social, mobile, analytics, and cloud are used by companies globally in order to achieve their goals in efficiency, customer engagement, and consequently, income increase. Each company has its own approach and follows a different path in its digital journey, having reached different levels of digital maturity. However, as international studies prove, the acquisition and use of new digital technologies - or even the formation of a digital business strategy - are not always enough to achieve desired goals of digital transformation.

The following article is a summary of a dissertation prepared for the MBA Program of Hellenic Open University, and a relevant survey carried out on 124 Greek businesses from different sectors and industries from December 2019 and January 2020, which seeks to identify whether it is strategy or technology that induces digital transformation among Greek businesses and compares the results to those of international research and sources. The article investigates with questionnaires the perceptions of Greek businesses about their digital maturity, digital transformation approaches, and strategy objectives, along with implementation obstacles, attitudes to employees' digital skills development, and opinions on their leaders' ability to shape and coordinate digital strategy.

The findings of this study can be useful in creating an initial picture of perceptions and practices applied by Greek businesses to their use of digital technologies. Businesses of all sizes, dynamics, and industries can come into first contact with ideas for digital technologies they had not considered using and areas of business they did not believe could be improved or transformed, not to mention the main obstacles reported as the most frequently anticipated. Furthermore, business executives may collect information of different data and details that I examine and evaluate with the digital maturity model used in this study. The results of this study can also become a measure of comparison for those companies that choose to base their self-assessment on this specific model of digital maturity.

This article consists of five parts. After a brief synopsis of the content and purpose of the theme in the first part, the next one offers a short definition of digital transformation, a brief review of the internal and external pressures that businesses face toward digital transformation and its foundation stones as presented in the literature, along with the results of several international studies regarding digital business strategy, the targets and barriers in the implementation of digital strategies globally, a brief 
review of several existing digital maturity models and expectations of the expansion of digital technologies for the next years. Moreover, the second part briefly presents the situation of Greek digital economy and the integration of digital technology by Greek organizations in comparison with the average of the EU member countries. The third part presents the research methodology and its limitations. Part four contains the presentation and analysis of the data collected by the study questionnaires. Finally, the last chapter concludes and compares research findings to the international data.

\section{Key Drivers of Digital Transformation: Literature Review and International Data}

\section{Definition of Digital Transformation: Internal and External Pressures}

As researchers often mention, digital transformation cannot be easily defined. Westerman (2014) states that digital transformation "is the use of technology to radically improve performance or reach of enterprises." In general, "digital transformation" is used as a term to describe the process, impact, and change in the use of new digital technologies. In a more analytical definition, digital transformation is the integration of digital technologies such as social, mobile, analytics, cloud computing, and the Internet of Things (SMACIT) so as to transform three basic company levels: customer experience, business models, and operational processes (Westerman et al., 2011; White, 2012; Westerman, 2014; Ismail et al., 2017). In yet other words, a digitally transformed company integrates new digital technologies by enabling improved processes, engaging talents across the organization, and creating new business models that generate value (Kane et al., 2015).

The need for digital transformation derives from both internal and external reasons as observed in the literature. Internally, a strong motivation of companies toward digital transformation stems from their need to change core businesses due to decreasing sales (Hess et al., 2016; Ismail et al., 2017). Moreover, businesses are motivated by the need to facilitate the interaction and collaboration of employees, thus creating digital workplaces. They also respond to the increasing pressure to attract and maintain talented and inspired employees who are to prefer working for digitally-enabled companies (Westerman et al., 2011; White, 2012; Kane et al., 2015; Ismail et al., 2017). Other internal pressures toward digital transformation include the need to improve productivity and operational efficiency, the expectation of competitive differentiation through innovation, and the need to satisfy shareholders' pursuit for growth and value generation (Kane et al., 2015; Ismail et al., 2017). 
At the same time, several external pressures make the digital transformation of businesses essential for their preservation and development, including the need to respond to customer expectations. As Von Leipzig et al. (2017) emphasize, customers today not only demand their needs to be met but also expect companies to be prepared in advance for "their future needs before they themselves have realized them." Furthermore, new digital technologies such as SMACIT, artificial intelligence, blockchain, robotics, and virtual reality have totally changed the view of the marketplace, demanding a response from long-lasting companies that seek to retain their positions in their industries (Kaufman et al., 2015; Sebastian et al., 2017; Ismail et al., 2017). A company's transformation through new digital technologies has become the way to fight against increasing competition, especially start-ups, known for their innovation and industry disruption.

\section{Pillars of Digital Transformation}

As researched by Capgemini Consulting and MIT Sloan Management, the basic components for the foundation of a successful digital transformation are customer experience, operational processes, and business models (Fitzerald et al., 2013; Westerman et al., 2014). As Westerman et al. (2014) explain each one of these three main pillars consists of three elements, which as a total are called "the Nine Elements of Digital Transformation”. The foundation stone of every digital transformation strategy is digital capabilities.

\section{Customer Experience}

According to Westerman et al. $(2011 ; 2014)$ customer understanding, top line growth, and customer touchpoints are the three elements of digital transformation related to Customer Experience.

Investments in Customer Relationship Management (CRM) software and data analytics create the basis providing a detailed understanding of customer's preferences, needs, interests, complaints, and a deeper comprehension of market segments. Companies use social media to promote campaigns of products, services, and events, thus spreading advertising messages faster. Analytic capabilities can quickly gather big data and create a more targeted and individualized customer experience. Online communities can offer deeper knowledge on the change of consumer preferences in time and faster locate complaints.

New technological devices are used to improve and intensify in-person sales. Tablets are used during presentations. Mobile tools and applications like plug-ins offer personalized sales and services or customized product packages. 
Furthermore, most companies use digital channels to allow contact with customers. Online communities are built to better manage complaints, questions, and aftersales service, thus increasing brand loyalty. However, multichannel services are a challenge for companies, usually demanding changes in several operational processes to avoid communication gaps that can negatively affect customer experience.

\section{Operational Processes}

Process digitization, employee enablement, and performance management are - according to Westerman et al. $(2011 ; 2014)$ - the three elements of the digital transformation of operational processes that can offer significant benefits for a company.

Automation can increase process efficiency, improve quality, and save resources. Automated plants, investments in Enterprise Resource Planning (ERP) and Human Resources Information System (HRIS) software enabled with special features like Employees Self Service (ESS) can increase production and quality, transform many processes such as supply chains, reduce or reposition personnel (Westerman et al., 2014), automate payroll workflow, and even simplify the analysis of job applicants and their qualifications. Several collaborative and networking tools such as mobile e-mail, cloud services, video conferencing, webinars, and data and information exchange have completely transformed the working process and employee collaboration. Moreover, software like CRM, HRM, or ERP allows managers and executives to make decisions based on real data and information about customers, employees, production, and transactions and not on assumptions or last year's results.

\section{Business Models}

The three components of business model transformation are digital: modified business, new digital business, and digital globalization.

Companies are motivated to transform their businesses to survive. Physical stores are considered insufficient. Digital offerings and other e-commerce activities like "digital wrappers" and other alternative digital approaches can strengthen traditional business or replace products and services no longer needed. At the same time, new digital products are created to be offered separately or as complements that enhance or improve traditional ones: e.g. smart pens that synchronize handwritten notes made on the company's paper planners added to digital calendars and applications or sports clothing with devices providing performance data and reports.

Moreover, "global shared services" in critical sectors such as finances, HR, or manufacturing allow multinational companies to pursue the global market (Westerman 
et al., 2011), while centralized data offer local managers a broader view of the global business status, which allows them to follow company guidelines tailored to the needs and conditions of the local business. Furthermore, local and national companies (e.g. manufacturing and exporting companies) may take advantage of the international marketplace through specialized digital platforms and systems (e.g. Alibaba) that offer operational, communication, marketing, sales, and other tools, along with tools for digital payment, partnership with suppliers, trade insurance, financing solutions, logistic, shipping, and other services.

\section{Digital Capabilities}

Digital platforms that offer unified data of customers and products, along with unified processes, are the basis for the success of the implementation of multi-channel services and operations. In that regard, the key tools are CRM, HRM, and ERP systems. The existence of the position of a Chief Information Officer - responsible for the design and the implementation of the digital strategy of the company and an IT department - is a starting point, but they are not enough. Analytics and specialized digital skills must be organized in such a way as special innovation or digital transformation units that offering digital solutions customized to specific company needs (Reinsel et al., 2018).

\section{International Research}

Digital technologies - social, mobile, analytics, and cloud - have a lot of potential and offer many opportunities, but their adoption in any organization cannot guarantee a positive outcome, neither should we immediately interpret such adoption as digital transformation. Unfortunately, about 70\% of transformation programs fail (Bucy et al., 2016; Tabrizi et al., 2019). As Kane et al. explain in the international research of MIT Sloan and Deloitte University Press (2015), the power of digital technologies can be fully developed under a clear and holistic digital strategy driven by leaders who focus on changing business culture, overview, and process. According to the same research, a quarter (26\%) of companies globally are in an "early" stage of digital maturity, while $45 \%$ can be characterized as digitally "developing." Only $29 \%$ of companies globally can be classified as "maturing," having reached a higher level of digital transformation. Similar results were presented by IDG's research in 2018, according to which $44 \%$ of organizations have already adopted a digital business approach in operations, customer experience, and procedures. Gartner's Survey of 388 CEOs proves that $42 \%$ of them have started a digital transformation process in their companies (Gartner.INC, 2017).

Furthermore, most companies follow similar objectives by implementing a digital strategy. The 2018 international study by IDG shows that $64 \%$ of organizations believe that automation will provide operations efficiency, $58 \%$ expect to improve customer 
experience, and half of them estimates an increase in employee productivity. Similarly, MIT Sloan's international survey (2015) highlights that 55\% of companies expect to improve customer engagement, $45 \%$ believe that a digital business strategy will improve innovation, and 53\% aim to increase efficiency (Kane et al., 2015).

Moreover, most organizations face obstacles on their way to digital maturity. More than one-third (39\%) of companies globally find it difficult to finance their digital strategy (IDG, 2018), while an excess of priorities counts among the top obstacles (Kane et al., 2015). The lack of skilled personnel is another problem, faced by $36 \%$ of organizations (IDG's research 2018), which counts among the three top issues recorded by companies of medium to higher digital maturity according to the international MIT survey (Kane et al., 2015), while the top obstacle reported by companies at their early stage of digital transformation is the lack of strategy.

There are several digital maturity evaluating models. One of them is the Capgemini Consulting's and MIT Sloan's Digital Maturity Matrix (2011), which measures the transformation management intensity on its X-axis and digital intensity on its Y-axis while classifying businesses as "beginners," "fashionistas," "conservatives," and "digirati." Another digital maturity model is the McKinsey Global Institute's Industry Digitization Index (2015), which assesses 27 indicators that classify business sectors as having high, medium, or low digitization according to their digital assets, uses, and workers. Azhari et al.'s (2014) maturity model allows businesses to measure their digital performance in eight dimensions (strategy, leadership, products, operations, culture, people, governance, and technology) and classify themselves on five maturity levels (unaware, conceptual, defined, integrated, transformed). Furthermore, Venkatraman's Digital Matrix (2017) employs three basic players/competitors per industry and potential collaborators through the interaction of three phases that offer a roadmap to guide businesses in the assessment and analysis of their digital and business challenges and the formulation of a digital strategy, which can jointly offer a successful business transformation. For the purposes of this study, the participating businesses self-evaluated their closeness to digital transformation based on the Digital Maturity Matrix introduced by Kane et al. in the international research of MIT Sloan and Deloitte University Press (2015), according to which businesses are classified as digitally early, developing, and maturing.

Furthermore, differences in digitization levels also appear among different industry sectors (Kohli et al., 2011; Bughin et al., 2016; Kane et al., 2015). According to Kane et al. research in the USA (2015) and its Industry Digitization Index: ICT, the media, finance, and insurance prove to be among the sectors with the highest digitization, 
while healthcare, construction, and hospitality appeared among the sectors with fewer digital assets, practice, and related employees. Similarly, MIT Sloan' and Deloitte University's (2015) research proves that technology-related industries like IT, telecommunications, entertainment, and the media lead the race toward digital maturity worldwide.

According to Cearley et al. (2019), hyperautomation, multiexperience, augmented analytics, distributed cloud, autonomous things, blockchain technology, and AI security are among the "Strategic Technology Trends" that every company should consider when creating and promoting their digital business strategy for the next five years. No organization or corporate aspect will remain unaffected by digital progress. As Reinsel et al. (2018) note that the size of worldwide data stored in 2018 amounted to 33 Zettabytes with a prediction to reach 175 Zettabytes by 2025, 49\% of which will be stored in cloud environments. Therefore, companies need to use cloud services will keep increasing. Finally, Porter and Heppelmann (2017) emphasize the need of every business to examine several strategic issues due to the expected extent of augmented reality's impact in the years to come.

\section{Greece's Position in the European Digital Economy and Society Index}

We ask what the position of Greek companies regarding digital maturity is, and whether they are ready to encounter the rapid expansion of global digitalization. Based on the Digital Economy and Society Index (DESI) of the European Commission for 2019, Greece ranks only $27^{\text {th }}$ in such measures as connectivity, ICT specialists, the use of Internet services, the integration of digital technology, and the digitalization of public services. On the other hand, Greek businesses progressed since 2014 to hold 22nd place among the European member states, with an average score far below the EU average.

\section{Research Methodology}

The aim of this study was to assess strategy and technology as key drivers in Greek businesses' digital transformation efforts by the collection and analysis of their views on the stage of own digital maturity, their digital strategy approaches, objectives, and obstacles, their perceptions of own digital leadership, and employees' digital skills development. The research methodology I selected to collect relevant data was a quantitative survey that used a structured questionnaire. The questionnaire mostly based on the one created by Kane et al. (2014) for the international study by MIT Sloan Management Review and Deloitte University Press. The results and conclusions of their research 
were published in 2015 and stated that "strategy, not technology, drives digital transformation," which became one of the main sources of this article's bibliography and the basis for comparing data results of their survey. The designed questionnaire contained several questions from their survey, closed-ended or scaled, either in translation or modified to meet the peculiarities of Greek private businesses, along with several new ones seeking to obtain further information useful for my study, based on secondary data collected from the literature.

The procedure of questionnaire research was conducted online for the purpose of its faster and easier distribution and for data collection. Potential participants were approached with an e-mail containing the theme of the study, an explanation of its voluntary nature, a guarantee of anonymity for respondents and their businesses, and a link to the questionnaire. The procedure of questionnaire distribution and collection happened from December 2019 to January 2020. Furthermore, the abovementioned MIT's digital maturity evaluation model used in this surveys' questionnaire and analysis was chosen because it provided an easily applicable self-evaluation method for participating businesses with the additional opportunity of comparing results with similar international data.

The population of my study consisted of 124 Greek businesses from the private sector: $32 \%$ from the industry and manufacturing sector, $14 \%$ from the professional services sector, $12 \%$ from the retail sector, $7 \%$ from the tourism sector, $6 \%$ each from IT and the entertainment/media/publications sector, $5 \%$ from healthcare providers and services, $4 \%$ from the economic/financial/bank services, $3 \%$ from education businesses, $2 \%$ each from clothing and telecommunications sectors, $1 \%$ from the energy sector, and $6 \%$ from other sectors such as wholesale trade. Moreover, around $70 \%$ of the sample respondents held senior to higher positions in the sample businesses at the time of study: 30\% were CEOs, Presidents, Managing Directors, Vice-Presidents, or Members of the Board of Directors; 21\% were CFOs, Auditors, Financial Analysts, CIOs, or IT Managers; and 19\% were other Directors or Managers.

\section{Data Analysis and Results}

\section{General Information}

Almost all (97\%) of the businesses participating in the study declared having an online presence, e.g. a webpage, a Facebook page, a Google page. Nevertheless, 78\% of them declared that the percentage of their business turnover connected with their Internet 
presence or e-commerce amounts to less than $25 \%$ of their total turnover. Only the remaining $22 \%$ of studied businesses responded that they witness the higher portion of their income to result from their online presence (Figure 1).

Figure 1. Percentage of business turnover connected with e-presence/e-commerce among the Greek businesses with an online presence (e.g. webpage, Google page)

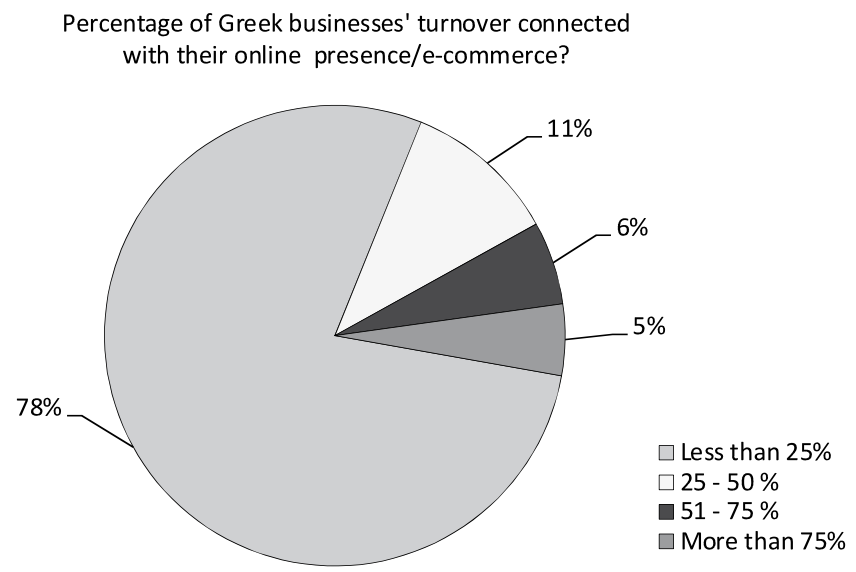

Source: own elaboration.

Furthermore, according to my questionnaire results analysis about the extent of use of several digital technologies by Greek businesses (Figure 2), I clearly saw that even though digital technologies tend to be used by a large part of Greek private businesses, there seems to still exist a large part of Greek private sector in which digital technologies are not used at all, with the sole exception of e-banking, whose extended use by the vast majority of Greek businesses (73\%) can be safely attributed to the restrictions imposed on the banking sector and the handling of money during the recent years of Greek economic crisis.

More specifically, 61\% of Greek private businesses declared using social networks such as Facebook, LinkedIn, Skype, WhatsApp, and Viber to a moderate (31\%) or great extent (30\%). Collaborative technologies like synchronized and unsynchronized educational platforms, communicative technologies, time management technologies, and emails were used by more than half (54\%) of Greek businesses to a great (31\%) and moderate (23\%) extent. Cloud services were also used extensively (47\%), with $27 \%$ of the respondents reporting their use to a great and $20 \%$ to a moderate extent. Moreover, $44 \%$ of them used mobile applications, e.g. in sales departments for providing information to costumers, enabling employee communication and collaboration, or remote 
control of digital platforms: $21 \%$ of studied businesses to a great and $23 \%$ to a moderate extent. The same percentage declared using digital marketing techniques such as Google Ads, banners, social media ads, YouTube ads, influencers, and emails either to a great $(19 \%)$ or to a moderate (25\%) extent. Data collection and analysis such as Web Analytics, Google Analytics, or Facebook Insights were also quite popular among Greek businesses, with $43 \%$ of them reporting their great (20\%) to moderate (23\%) use. The least used digital tool by Greek private businesses was e-commerce, which was used to a great or moderate degree by only $34 \%$ of them.

Contrary to the above, as shown in Figure 2, a quite large part of Greek businesses uses just a few or no digital technologies at all. More specifically, 40\% reported not using e-commerce at all and around 30\% does not use digital marketing techniques, mobile applications, cloud services, and data collection and analytics. Collaborative technologies are not used by $23 \%$ of Greek private sector businesses, but only $16 \%$ report no use of social networks. These percentages can be considered quite high when compared to those of the international research by MIT Sloan and Deloitte (Kane et al., 2015).

Figure 2. The extent of use of digital technologies by Greek businesses

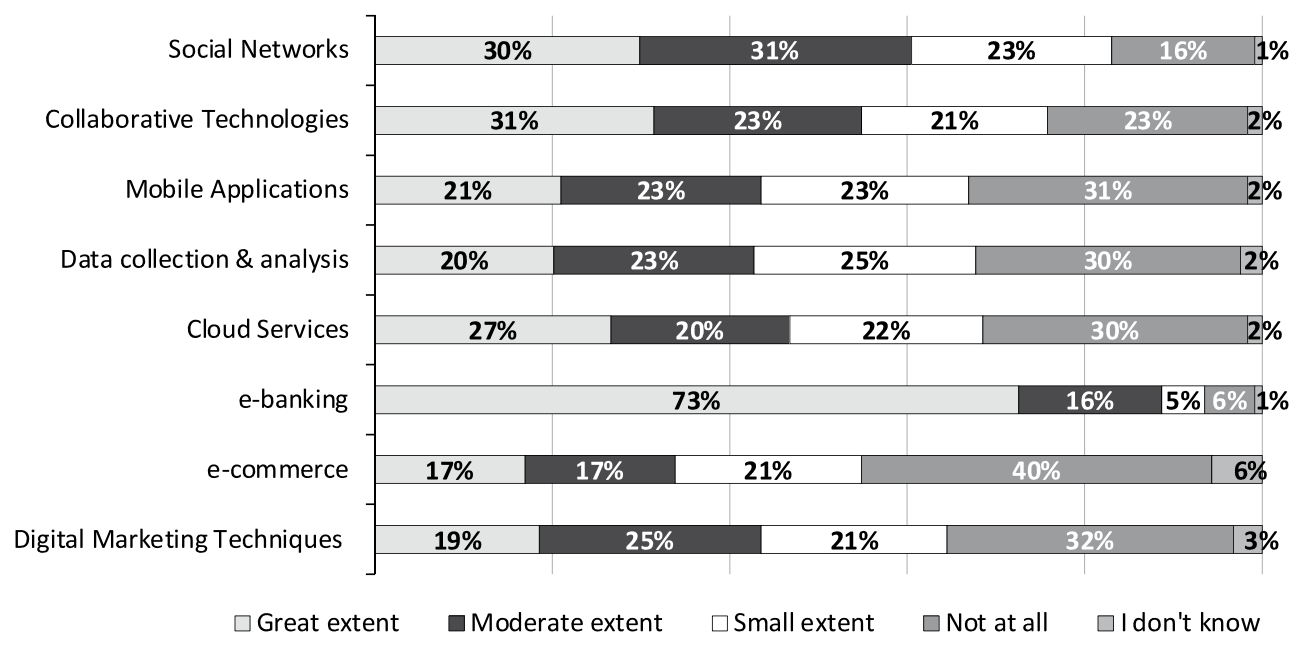

Source: own elaboration.

\section{Digital Strategy and Digital Maturity of Greek Businesses}

The data collected by this study's questionnaire offers important information and insights about perceptions of businesses in the Greek private sector on their digital strategy and their digital maturity. Respondents were asked to evaluate their businesses' closeness to digital transformation on a scale of 1 to 10 , following the classification 
by Kane et al. (2015) and based on a definition also expressed by them according to which "a digitally transformed business is organized and operates based on digital technologies improving its processes, has trained and developed its talented employees and has introduced new business models that create value." Figure 3 shows the results of each level from 1 to 10 in which 1 means "not at all close" and 10 "very close." Most Greek businesses position themselves in medium levels of digital maturity. A few seem to be closer to ideal digital transformation, while several seem to have just begun the journey (Figure 3). Following the same MIT Sloan and Deloitte's categorization of digital maturity (Kane et al., 2015), I classified the 10 levels in three groups: "early," "developing," and "maturing." The "early" group consists of levels 1 to 3, the "developing" group of levels 4 to 6, and the "maturing" one of levels 7 to 10. As a result, 29\% of Greek companies position themselves at an early stage of digital transformation, $38 \%$ of them at the stage of digital development, and 33\% can be characterized as digitally "maturing” (Figure 4).

Figure 3. Levels of Greek businesses' digital maturity

Greek Businesses' Digital Maturity Levels

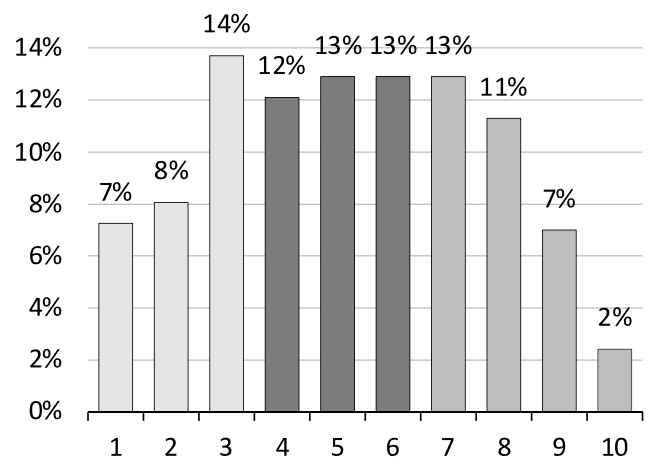

Source: own elaboration.
Figure 4. Groups of digital maturity

Greek Businesses' Digital Maturity Groups

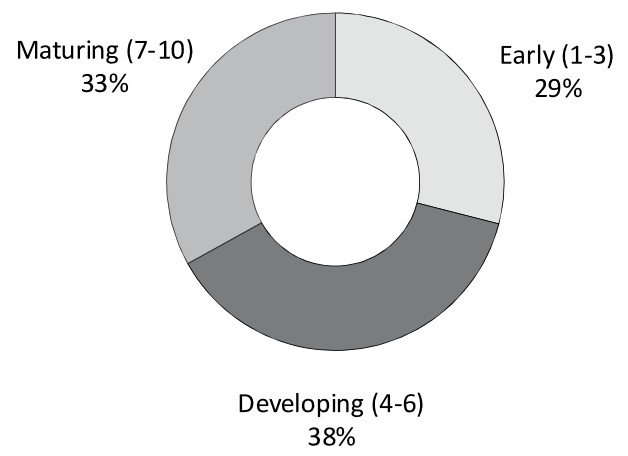

Source: own elaboration.

We would need to account for more factors in order to more thoroughly assess the similarities and differences among Greek businesses of the three different digital maturity groups as the above resulted from their self-evaluation.

Therefore, I observed that only 11\% of respondents located their businesses in the early stages of digital transformation report having "a clear and coherent digital strategy" (Kane et al., 2015). This percentage increased among businesses that belong to the "developing" stage, in which $32 \%$ of respondents "strongly agree" or "agree" to the same, 
and it reaches 78\% among those from maturing companies. Moreover, 98\% of respondents from maturing Greek businesses reported an understanding of the goals that their businesses want to achieve with the use of digital technologies (Figure 5). At the same time, only $69 \%$ of respondents from early businesses seemed to understand the goals of their businesses' digital strategy. In other words, those respondents who evaluated their businesses as belonging to higher stages of digital transformation considered them also to have a well-structured digital strategy and declared being conscious of its goals. This significant increase agrees with the research results of Kane et al. (2015) who indicate the importance of a clear and coherent strategy - well communicated and understood among their members - for the digital transformation journey of businesses.

Figure 5. Respondents' i) agreement on the clarity and coherency of their businesses' digital strategy, ii) understanding of goals of their businesses' digital strategy, categorized by group of business maturity

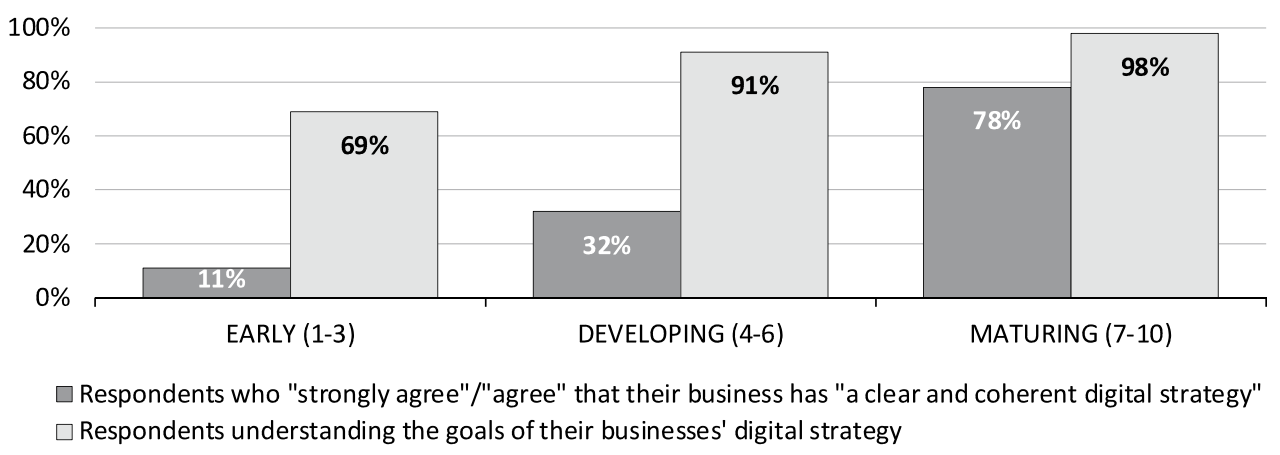

Source: own elaboration.

Furthermore, almost $40 \%$ of respondents who positioned their businesses in the early stages of digital maturity disagreed or strongly disagreed with the notion they have a clear and consistent digital strategy. The relevant percentage of developing stage businesses was $22 \%$, while only $3 \%$ of respondents from maturing businesses considered the same. The existence of a clearly stated digital strategy appeared to coexist in respondent's perceptions with higher levels of digital maturity and its lack at lower levels of digital transformation stages.

The differences among the three groups of digital maturity also appeared in the matter of their digital strategy objectives, as shown by Figure 6 . When asked to express their view about the objectives of their businesses' digital strategy, respondents from businesses at early stages of digital maturity chose those related mainly to efficiency, productivity, and customers. More specifically, 53\% of them believed that their busi- 
nesses aim to improve the understanding of customer preferences and behavior, $47 \%$ to improve customer experience and loyalty, and $49 \%$ to increase efficiency and improve innovation. Only a small percentage agreed that their digital strategy seeks to improve the process of business decision-making (17\%), essentially transform the business processes (34\%), or change the business model (42\%).

On the other hand, as it is obvious from Figure 6, the majority of maturing stage businesses seemed to target all the basic components of the foundation of a successful digital transformation as presented above. In particular, according to their respondents' opinions, the transformation of business processes and models were the objectives among 92\% and $73 \%$ of maturing businesses, respectively; the improvement of the decision-making process was the target of the digital strategy of $82 \%$; $90 \%$ sought innovation improvement; $91 \%$ focused on efficiency increase; $90 \%$ wanted to improve the understanding of customer preferences and customer behavior; and $82 \%$ endeavored to improve customer experience and loyalty. Maturing businesses seemed to follow holistic digital strategies that address and include every aspect of the company in order to obtain a successful digital business transformation. On the contrary, the respondents from early-stages businesses showed that these choose partially focused objectives, ignoring important aspects like the improvement of the decision-making process.

Figure 6. Respondents who "strongly agree" or "agree" about their businesses' digital strategy objectives by group of digital maturity.

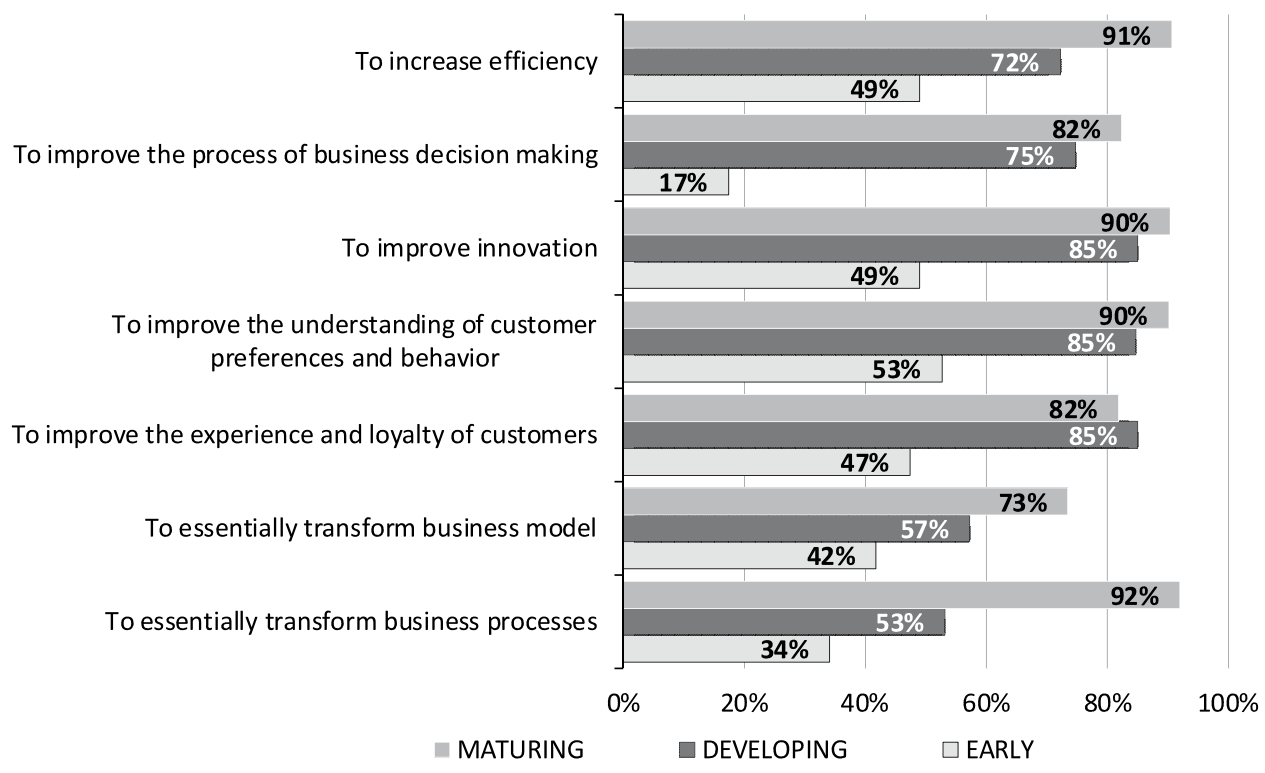

Source: own elaboration. 
Table 1 presents the four main obstacles that Greek businesses face in exploiting the transformative power of digital trends, according to the respondents from each group of business maturity level. The lack of an overall strategy was the main problem noted by respondents from businesses on both early and developing stages of digital maturity by $36 \%$ and $38 \%$ of them, respectively. The lack of understanding by managers and the lack of organizational flexibility were further barriers considered by $33 \%$ of respondents from the early stages of digital maturity businesses. On the other hand, the lack of technical skills of employees was reported as an obstacle by $32 \%$ of respondents from developing businesses, ranking second on their obstacles list, and - even though it is not among the three most frequent options of respondents from maturing businesses - it remained quite an important barrier among them too, ranking fourth on their list (20\%). On top of the obstacles list of maturing businesses was the large number of competing priorities according to almost a quarter (24\%) of their respondents. However, it was quite interesting that the same percentage of respondents from maturing businesses believed that there were no obstacles to fully benefiting from digital trends. Finally, the third barrier on the list of both maturing and developing businesses, ranking fourth for the early businesses $-22 \%, 28 \%$, and $28 \%$, respectively - was the lack of funding. Such an obstacle may be considered normal, given the financial crisis that Greece has been experiencing in the last decade.

\section{Table 1. Four main obstacles of digital transformation}

\begin{tabular}{|c|c|c|c|c|c|}
\hline \multicolumn{6}{|c|}{$\begin{array}{l}\text { The four main obstacles that businesses of different levels of digital maturity face } \\
\text { in exploiting digital trends }\end{array}$} \\
\hline EARLY & $\%$ & DEVELOPING & $\%$ & MATURING & $\%$ \\
\hline $\begin{array}{l}\text { Lack of an overall } \\
\text { strategy }\end{array}$ & $36 \%$ & $\begin{array}{l}\text { Lack of an overall } \\
\text { strategy }\end{array}$ & $38 \%$ & $\begin{array}{l}\text { A large number } \\
\text { of competing priorities }\end{array}$ & $24 \%$ \\
\hline $\begin{array}{l}\text { Lack of understanding } \\
\text { by managers }\end{array}$ & $33 \%$ & $\begin{array}{l}\text { Lack of technical skills } \\
\text { of employees }\end{array}$ & $32 \%$ & There are no obstacles & $24 \%$ \\
\hline $\begin{array}{l}\text { Lack of organizational } \\
\text { flexibility }\end{array}$ & $33 \%$ & Lack of funding & $28 \%$ & Lack of funding & $22 \%$ \\
\hline Lack of funding & $28 \%$ & $\begin{array}{l}\text { A large number of } \\
\text { competing priorities }\end{array}$ & $23 \%$ & $\begin{array}{l}\text { Lack of technical skills } \\
\text { of employees }\end{array}$ & $20 \%$ \\
\hline
\end{tabular}

Source: own elaboration.

Furthermore, respondents were asked to characterize their business compared to their competitors in terms of the use of technologies. As we may see in Figure 7, 20\% of Greek maturing businesses appeared to create and use innovative technologies inaccessible to competition, $41 \%$ used technologies not widely known by competitors, and 
$32 \%$ used technologies popular among competitors. These percentages can be indicative of the competitiveness of digitally maturing businesses, especially since only $8 \%$ of businesses at early stages reported creating and using technologies inaccessible to competition or not widely known by competitors. About $42 \%$ reported only trying to follow technologies used by competitors, while almost a fifth of them (19\%) used no technology. Developing businesses simultaneously appeared to perform better with the use of technologies not widely known by competitors (26\%), while $38 \%$ achieved at least the use of technologies popular among competitors. As a result, it is quite obvious that business transformation through new digital technologies offers useful tools against increasing competition, especially against start-ups, known for their innovation and industry disruption.

Figure 7. Comparison with competitors in terms of use of technologies for each group of business digital maturity

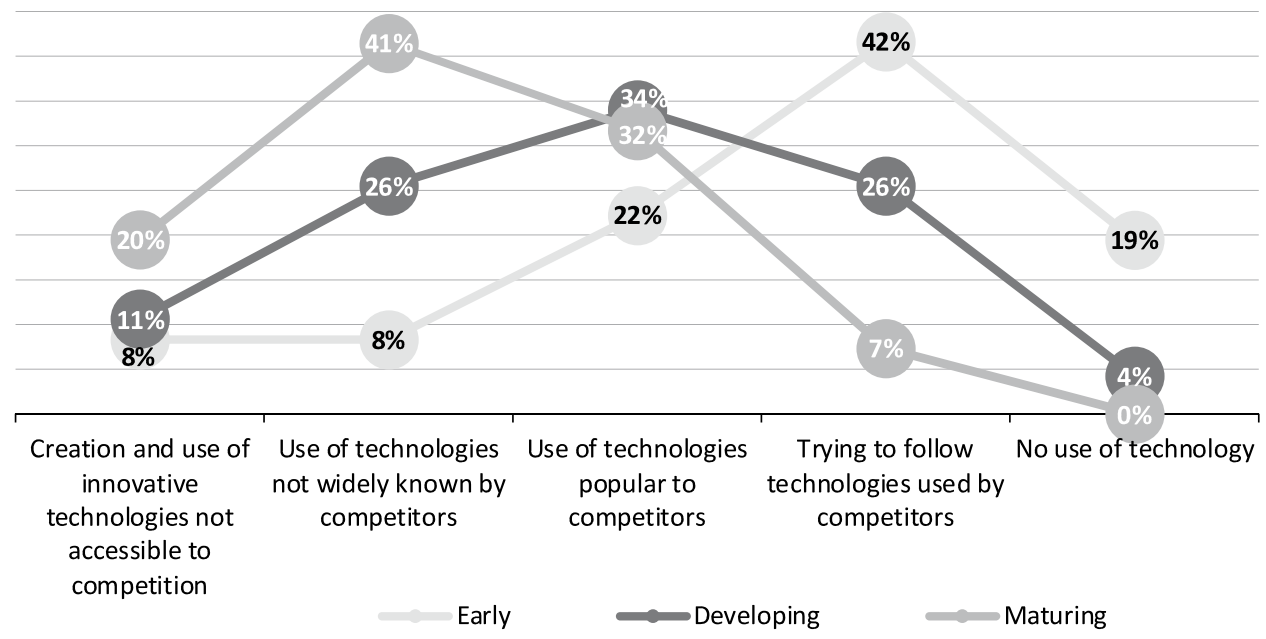

Source: own elaboration.

\section{Integration of Technology Across Businesses}

To understand the degree of integration of technology across businesses, the respondents were asked about the percentages of their companies' overall budget for digital technologies, along with last year's percentages of software and hardware equipment in total assets. According to the results, $67 \%$ of Greek businesses at the early stages of digital maturity and half of developing ones showed purchases/rent of hardware equipment (e.g. computers, servers) and software (e.g. ERP) to not exceed 5\% of their overall budgets. On the other hand, businesses at maturing stages appeared to be spending more than $5 \%$ of their overall budget on telecommunications and software 
and hardware purchases/rent (61\%, 54\%, and 71\%, respectively), while their estimable percentage even exceeded $10 \%$ of their overall budget $(29 \%, 17 \%$, and $34 \%$, respectively), and around one in ten even exceeded $25 \%$ of their last year's overall budget.

In the same way, software (e.g. owned software licenses) and hardware equipment (e.g. computers, servers) accounts for less than 5\% of total assets according to the answers of more than $75 \%$ of businesses at the early stages of digital transformation. At the same time, hardware equipment accounts for more than $5 \%$ of total assets for $70 \%$ of maturing stages businesses, while for $24 \%$ of them, it even exceeds $10 \%$ on total assets. Similarly, software (e.g. owned software licenses) accounts for more than $5 \%$ of total assets according to $60 \%$ of maturing stages businesses, with $30 \%$ of them responding that software exceeds $10 \%$ on total assets. Overall, Greek maturing companies appeared to invest more in digital technologies on a temporary as well as on a more permanent basis.

\section{Use of Digital Technologies}

In further analysis, the use of specific digital technologies by Greek businesses based on their different maturity groups mostly showed that maturing businesses present a greater and more expanded use of different digital technologies (Figure 8).

Figure 8. Use of digital technologies by digital maturity group

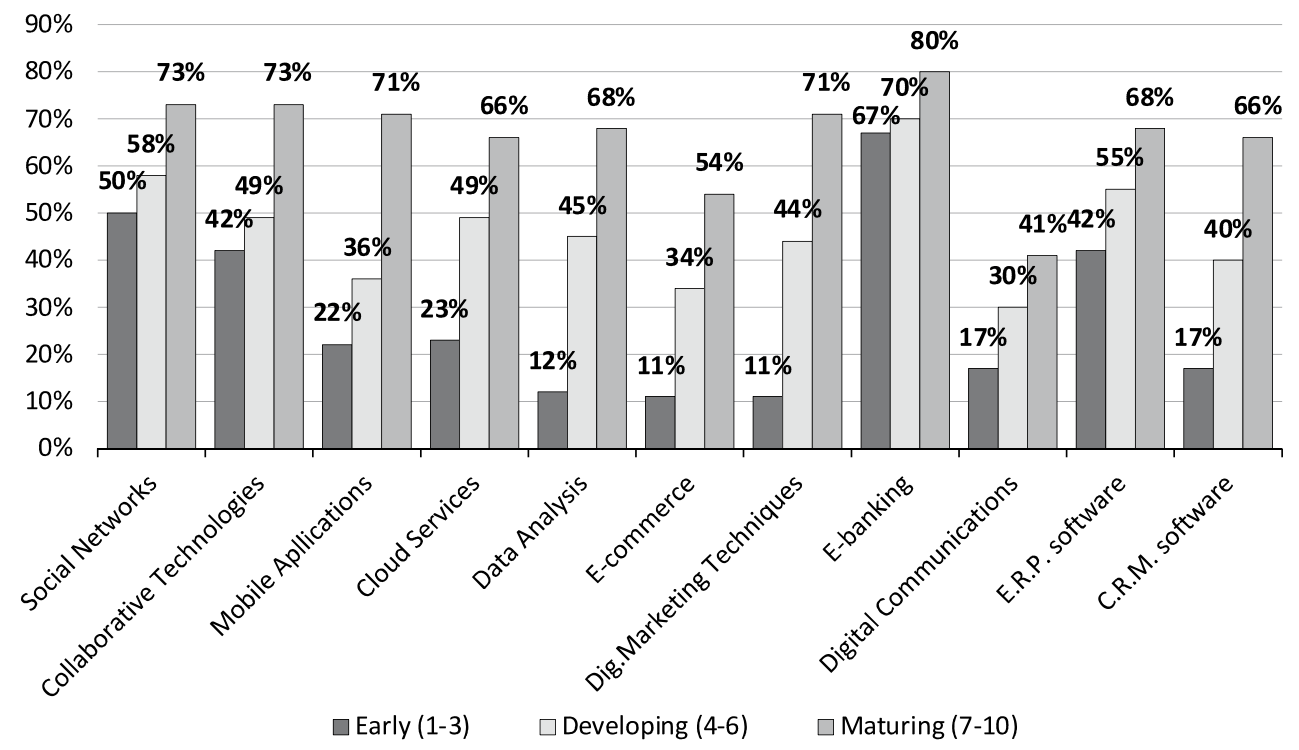

Source: own elaboration. 


\section{Use of Digital Channels}

Digital channels such as social networks, collaborative technologies, and mobile applications can be used in many ways such as in employee education and collaboration, even in product promotion or complaints management. As we observed in Figure 8, the percentage at which Greek businesses use digital channels to a great or moderate extent increases as their digital maturity rises. More specifically, around $70 \%$ of maturing businesses were reported by the respondents who use the digital channels to a great or moderate extent, while relevant percentages of early and developing businesses appeared to be, respectively, $50 \%$ and $28 \%$ for social networks, $42 \%$ and $49 \%$ for collaborative technologies, and only $22 \%$ and $36 \%$ for mobile applications. At the same time, respectively $56 \%$ and $39 \%$ of businesses at early and developing stages of digital maturity were reported to not use mobile applications and collaborative technologies.

Businesses use digital channels to communicate with consumers, suppliers, employees, and partners/collaborators, but only $17 \%$ of businesses at early stages of digital maturity declared using digital channels to communicate with all the above, against $41 \%$ of the maturing ones. Moreover, respectively $58 \%, 47 \%, 31 \%$, and $39 \%$ of respondents from early-stage businesses "strongly agree" or "agree" that their businesses benefited from communicating with consumers, suppliers, employees, and partners/collaborators, against $88 \%, 76 \%, 78 \%$, and $88 \%$ of digitally maturing businesses.

\section{Use of ERP and CRM Software}

Furthermore, only $17 \%$ of Greek businesses at the early stages of digital maturity reported using CRM software, while the relevant percentage among developing businesses was $40 \%$ and $66 \%$ among maturing ones. Similarly, ERP software was used by $42 \%$ of early-stage Greek businesses, $55 \%$ of developing, and $68 \%$ of the maturing ones.

Most respondents whose companies were reported using ERP software, "strongly agreed" or "agreed" that it benefited their businesses: 93\% of maturing, 81\% of developing, and $80 \%$ of early-stage businesses. Instead, almost a third of the respondents who reported using CRM software were ambivalent about its positive impact, since only $70 \%$ of respondents from maturing businesses, 53\% from developing, and 67\% from early businesses that were using CRM software "strongly agreed" or "agreed" that it benefited their businesses.

\section{Use of E-commerce}

Interestingly, 54\% of Greek maturing businesses reported using e-commerce to a great or moderate extent, against $34 \%$ of developing businesses and only $11 \%$ of businesses at the early stage of digital maturity, which actually use e-commerce solely to a moderate 
extent (Figure 8). Similarly, only 8\% of Greek businesses at the early stages of digital maturity answered that they use software to develop new products, and only $3 \%$ use digital auctions as a source for business income, against $54 \%$ and $12 \%$ of maturing ones, respectively (Figure 8). These differences are compatible with and can be explained by the general differences between the digital strategy objectives of the three digital maturity levels and, more specifically, by the earlier research findings that $73 \%$ of maturing businesses aimed to essentially transform their business models through digital strategy, against $57 \%$ of developing and only $42 \%$ of early-stage businesses (Figure 6).

\section{Use of Digital Marketing Techniques / Data Collection and Analysis / Cloud Services}

Digital marketing techniques, cloud services, along data collection and analysis relate to the foundation stones of digital transformation, offering multiple benefits to several different parts of a company. Maturing businesses once more show higher percentages in this area as $71 \%$ of them reported using digital marketing techniques to a great or moderate extent, $68 \%$ - data collection and analytics, and 66\% - cloud services (Figure 8). The respective percentages of early-stage businesses were only $11 \%, 12 \%$, and $23 \%$, respectively, while $56 \%, 58 \%$, and $50 \%$ made no use of these digital tools at all.

\section{Use of E-Banking}

As I noted above, the only digital technology used by the majority of Greek Businesses is e-banking (73\% to a great extent; see Figure 2). The extent of e-banking use did not change significantly with the level of digital maturity (Figure 8), even though maturing businesses still report slightly higher rates of using it to a great extent (80\%) compared to those of developing and early-stage businesses (70\% and $67 \%$ respectively).

\section{Use of Digital Technologies by Personnel}

Employee enablement counts among the three basic elements for the digital transformation of operational processes (chapter Operational Processes). Several new digital technologies such as mobile e-mail, cloud services, or video conferencing software can fully transform almost all the working process, training, and employee collaboration, thus improving working conditions. This ability of digital technologies to essentially transform how people work was supported by $85 \%$ of respondents from Greek maturing businesses and close to $65 \%$ from businesses at early and developing stages.

The average working time during which employees of Greek private businesses reported to be using digital technologies differs among the three levels of digital maturity. In almost half of Greek maturing businesses, respondents considered that their employees 
spend more than $50 \%$ of their working time using digital technologies (Figure 9). On the contrary, in $67 \%$ of early-stage businesses, employees were reported using digital technologies in less than $25 \%$ of their working time.

Figure 9. Employees' average working time using digital technologies by businesses' digital maturity group

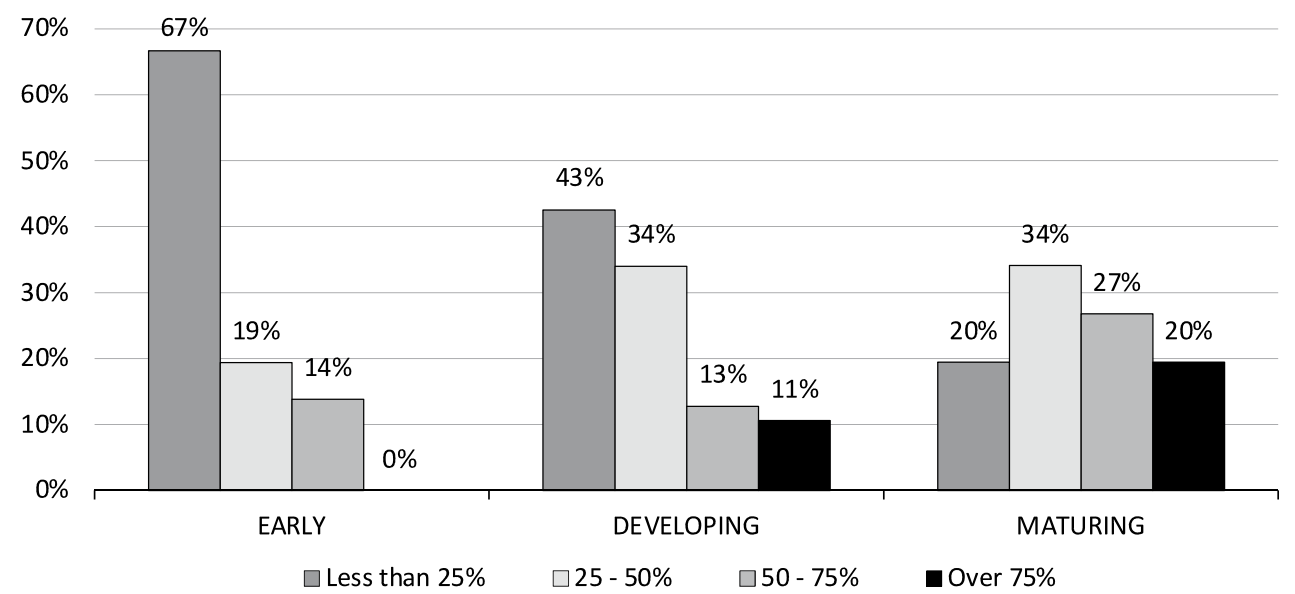

Source: own elaboration.

The vast majority of respondents (86\%) - regardless of the age group - considered it "very important" or "important" to work for a high digital capabilities company. Nevertheless, the lack of employees possessing the necessary skills and abilities to work with digital technologies is a problem that many Greek businesses face regardless of their digital maturity level. The challenge to find and preserve such employees is quite serious, especially because only $19 \%$ of respondents from businesses at early stages of digital maturity, $45 \%$ from developing stages, and $66 \%$ from maturing ones believe that their business employees have adequate digital skills to follow and apply their digital strategy (Figure 10).

To overcome this obstacle Greek businesses at the maturing stage seemed to understand the necessity for their employees to be properly trained and hence $90 \%$ of them reported providing their employees to a great extent or moderately with resources and opportunities to acquire the right skills concerning new digital trends (Kane et al., 2015). The relevant percentage of businesses at the developing and early stages of digital maturity was only $53 \%$ and $27 \%$, respectively (Figure 11). In fact, almost half (47\%) of the respondents from businesses at early stages reported that their businesses provide no such resources or opportunities at all. 
Figure 10. Businesses by group of digital maturity whose employees are digitally skilled to follow and apply digital business strategies

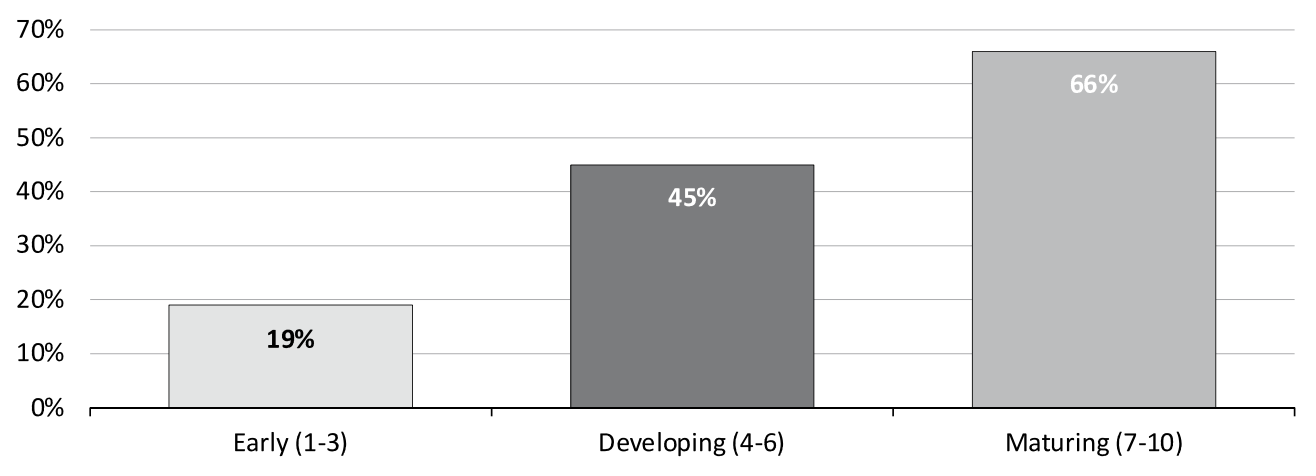

Source: own elaboration.

In the same way, $93 \%$ of respondents from digitally maturing businesses "strongly agreed" or "agreed" that their business motivates its employees to take initiatives and innovate using digital technologies (Figure 11), which agreed with the percentage of maturing businesses (90\%) that consider improving innovation as an objective of their digital strategy (Figure 6). On the contrary, less than half of respondents from businesses at the early and developing stages of digital maturity (44\% and $40 \%$ respectively) "strongly agreed" or "agreed" that their employees are encouraged toward such initiatives and innovation.

Figure 11. Employees digital enablement by group of business digital maturity

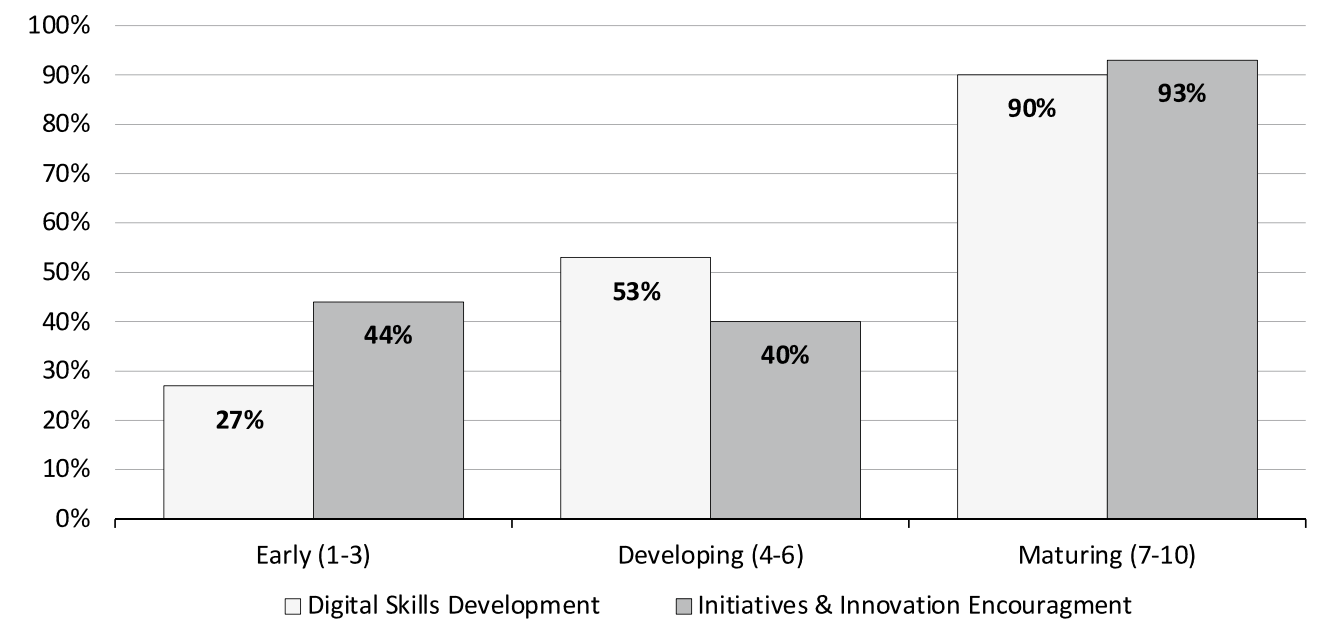

Source: own elaboration. 


\section{Digital Leadership}

The importance of the person responsible in the company for the planning and direction of businesses digital strategy is highlighted by literature (Kohli et al., 2011; Singh et al., 2017). The vast majority of respondents from maturing businesses answered that their businesses' digital strategy is directed by a person or a group of persons (Figure 12). In half of the cases, that person was to hold a high executive position like that of the Chief Executive Officer (CEO), Chief Financial Officer (CFO), Chief Operating Officer (COO), or Chief Information Officer (CIO). Only 31\% of the respondents form early-stage businesses and $60 \%$ from the developing ones report the existence of a person with such responsibilities in their businesses.

Moreover, while 83\% of respondents from Greek maturing businesses believed that their leaders have adequate skills and abilities to shape and coordinate their digital strategy, the percentage dropped to only $31 \%$ among those from early-stage businesses (Figure 12).

Figure 12. Digital leadership by group of digital maturity

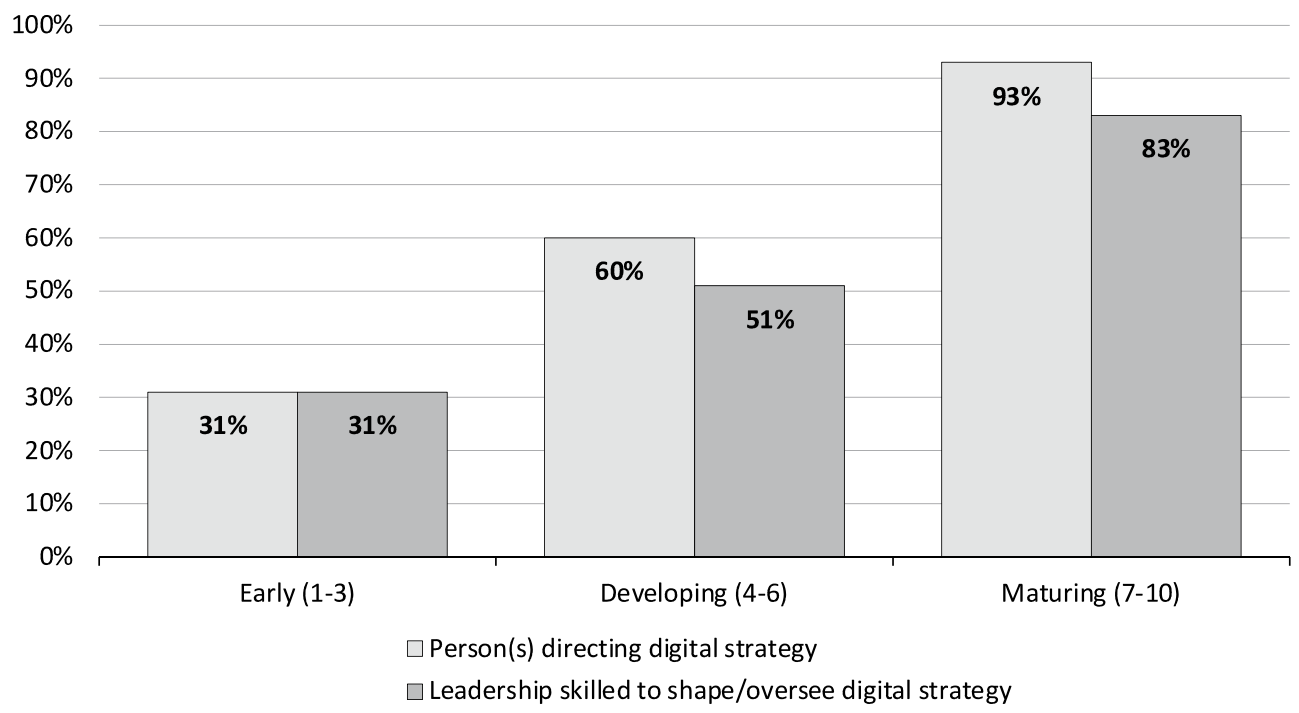

Source: own elaboration.

Furthermore, the existence of the person leading Greek businesses' digital strategy is not always accompanied by a separate digital transformation or IT department. More specifically, according to the results of my survey, only 16 of the 124 Greek businesses 
responded that they have a separate digital transformation department, while 41 of 124 responded that they have a separate IT department (13\% and $33 \%$ of the sample population respectively). Even though these results seemed to be quite low, they remind that $22 \%$ and $49 \%$ of maturing stage businesses reported having separate DT and IT departments, respectively, while the relevant percentages for early-stage businesses reached only $3 \%$ and $19 \%$ (Figure 13).

\section{Skills and Capabilities Lacking in Greek Businesses}

Figure 13. Greek businesses with a separate DT or IT department by level of digital maturity

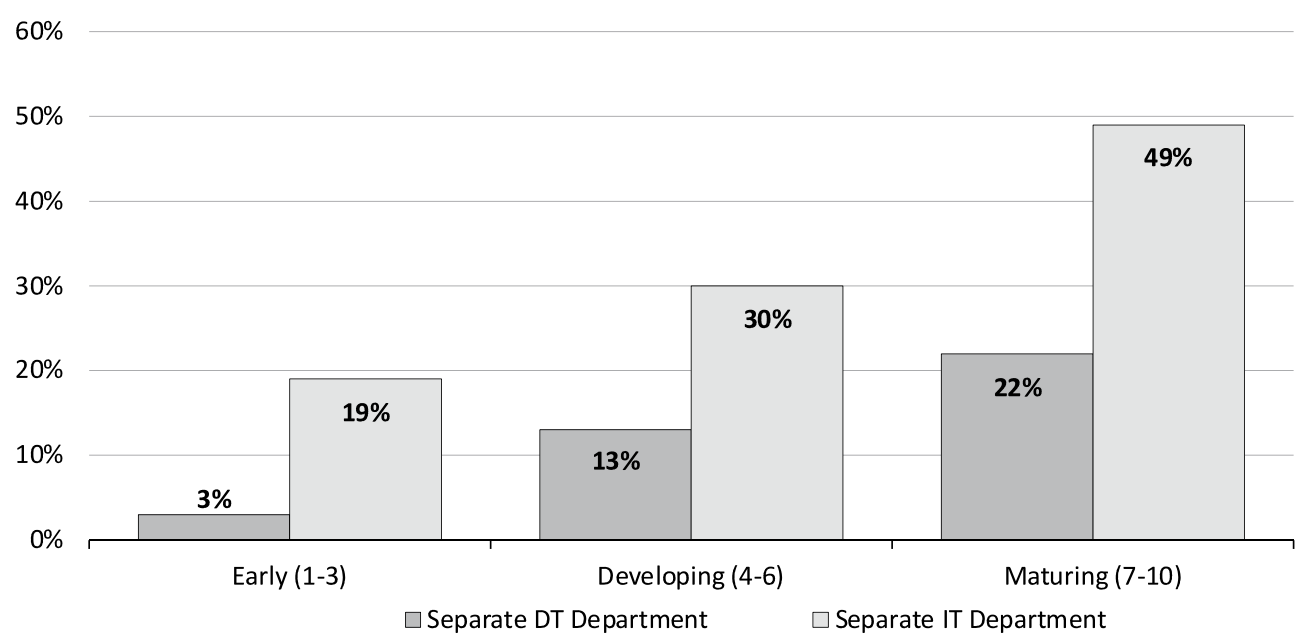

Source: own elaboration.

Furthermore, according to half of the respondents from both early - and developing-stage businesses, the ability most lacking among their companies' leaders and employees is - as Kane et al. (2015) aptly state - that of understanding how digital technologies can positively or negatively affect business processes and model. Only one-third of respondents from maturing businesses considered this a deficiency of their colleagues. Furthermore, around $45 \%$ of respondents - regardless of their level of digital maturity - believed that the mood for experimenting and taking initiatives and risks lacks among their colleagues. Moreover, the ability to understand their business' capabilities and needs was considered lacking by nearly one-third of respondents in companies from early and developing stages businesses and a quarter of maturing ones. Finally, teamwork and cooperation to achieve desired goals were considered the least lacking ability of leaders and employees at every stage of digital maturity companies. 


\section{Discussion}

This survey aimed to assess strategy and technology as key drivers of Greek businesses' digital transformation by analyzing the differences existing between the businesses of the three digital maturity categories (early, developing, and maturing), formulated after the self-evaluation of 124 Greek businesses that partook in this research. The main differences identified among the three categories concerning their perceptions about the stage of their digital maturity, their digital transformation approaches and objectives, certain implementation obstacles, their attitudes about employees' digital skills development, and their opinions on their leaders' ability to shape and coordinate the digital strategy, are outlined in Table 2, along with a comparison with the relevant results of the international research of MIT Sloan Management Review and Deloitte University Press (Kane et al., 2015) on the key drivers of digital transformation.

Table 2. Summary table of the main differences among the three digital maturity stages and comparison with the international research of MIT Sloan \& Deloitte (2015)

\begin{tabular}{|c|c|c|c|}
\hline & $\begin{array}{c}\text { EARLY (29\%) } \\
26 \% *\end{array}$ & $\begin{array}{c}\text { DEVELOPING (38\%) } \\
45 \% *\end{array}$ & $\begin{array}{c}\text { MATURING (33\%) } \\
29 \% *\end{array}$ \\
\hline Barriers & Lack of strategy on $33 \%$ & Lack of strategy on $38 \%$ & $\begin{array}{l}\text { A large number } \\
\text { of competing priorities } \\
\text { or } \\
\text { No obstacles }\end{array}$ \\
\hline Strategy & $\begin{array}{l}11 \% \text { with a clear } \\
\text { and coherent strategy } \\
\text { Objectives: } \\
\text { customer experience and } \\
\text { understanding, } \\
\text { productivity }\end{array}$ & $\begin{array}{l}32 \% \text { with a clear } \\
\text { and coherent strategy } \\
\text { Objectives: } \\
\text { customer experience and } \\
\text { understanding, innovation }\end{array}$ & $\begin{array}{l}78 \% \text { with a clear } \\
\text { and coherent strategy } \\
\text { Objectives: } \\
\text { target all elements } \\
\text { of digital transformation } \\
\text { among which (over } 82 \% \text { ) } \\
\text { transformation } \\
\text { of business processes, } \\
\text { decision making, } \\
\text { innovation } \\
81 \% *\end{array}$ \\
\hline $\begin{array}{l}\text { Digital Skills } \\
\text { Development }\end{array}$ & $\begin{array}{l}27 \% \text { provide their } \\
\text { employees with resources } \\
\text { and opportunities } \\
\text { to acquire the right skills } \\
\text { concerning new digital } \\
\text { trends } \\
19 \% *\end{array}$ & $\begin{array}{l}53 \% \text { provide their } \\
\text { employees with resources } \\
\text { and opportunities } \\
\text { to acquire the right skills } \\
\text { concerning new digital } \\
\text { trends } \\
43 \% *\end{array}$ & $\begin{array}{l}90 \% \text { provide their } \\
\text { employees with resources } \\
\text { and opportunities } \\
\text { to acquire the right skills } \\
\text { concerning new digital } \\
\text { trends } \\
76 \% *\end{array}$ \\
\hline
\end{tabular}




\begin{tabular}{l|l|l|l|}
\hline Leadership & $\begin{array}{l}31 \% \text { have adequate skills } \\
\text { and abilities to shape and } \\
\text { coordinate digital strategy }\end{array}$ & $\begin{array}{l}\text { 51\% have adequate skills } \\
\text { and abilities to shape and } \\
\text { coordinate digital strategy }\end{array}$ & $\begin{array}{l}83 \% \text { have adequate skills } \\
\text { and abilities to shape and } \\
\text { coordinate digital strategy }\end{array}$ \\
\hline $15 \% *$ & $39 \% *$ & $76 \% *$ \\
\hline $\begin{array}{l}\text { Person(s) } \\
\text { directing } \\
\text { digital } \\
\text { strategy }\end{array}$ & $\begin{array}{l}\text { In } 31 \% \text { there is a person } \\
\text { or group of persons } \\
\text { directing digital business } \\
\text { strategy }\end{array}$ & $\begin{array}{l}\text { In } 60 \% \text { there is a person } \\
\text { or group of persons } \\
\text { directing digital business } \\
\text { strategy }\end{array}$ & $\begin{array}{l}\text { In 93\% there is a person } \\
\text { or group of persons } \\
\text { directing digital business } \\
\text { strategy }\end{array}$ \\
\hline $\begin{array}{l}\text { *The relevant percentage of the } 2014 \text { research of MIT Sloan Management Review and Deloitte University Press, where } \\
\text { existing. }\end{array}$
\end{tabular}

Source: own elaboration.

Taking all into consideration, this survey showed that there is an evolution of the perception of digital strategy, its existence, objectives, and structure, which can be seen to develop and expand from the lowest to the highest levels of digital maturity.

Most Greek businesses at the early stages of digital transformation reported considerably limited use of digital technology trends and simultaneously the lack of a clear and coherent digital strategy. Almost half reported only trying to follow technology used by competitors, while digital transformation is mainly perceived by them as the use of technology to satisfy customer experience and improve efficiency. Even with its limited use, technology seems to have not been understood how and in which parts of the business can be used to assist its transformation.

On the other hand, most Greek businesses at the maturing stage of digital transformation reported greater use of different digital technologies, while 98\% of them simultaneously agreed or strongly agreed on having a clear and coherent strategy. The difference lies in the change of perceptions in how they use technology and to what end. These businesses seem to have understood that their transformation can occur only if they use technological trends to improve aspects like the decision-making process so as to innovate and transform their business model and processes while investing in the acquisition and retention of digitally competent employees.

Comparing the results of this study with those of the international research of MIT Sloan Management Review and Deloitte University Press (2015) on the key drivers of digital transformation, indicated in Table 2, we may observe that the differences between the percentages of the three categories of digital maturity of Greek businesses appear smaller than those of the international ones, in which almost half of the companies (45\%) consider themselves belonging to the "developing" group. Both studies 
revealed the same results about the differences of the digital strategy objectives declared by the three digital maturity stages businesses, as well as the lack of strategy to be one of the most serious obstacles of those positioning themselves at the early and developing stages and the existence of a large number of competing priorities as the highest-ranking obstacle of maturing stage businesses. Also, only 32\% of Greek developing businesses respond having a clear and coherent strategy against half of the international ones at the same digital stage.

Finally, according to the summarized results of this survey presented in Table 3, IT services, telecommunications, and health care services and providers are the business sectors that have the higher average rates of digital maturity among Greek private businesses, while the clothing industry appears to have the lowest rates. Furthermore, comparing the results of this survey with those of the similar international research of MIT Sloan Management Review and Deloitte (2015), several similarities and differences were noticed. Thus, in both surveys IT services and telecommunications seem to lead the race of digital transformation, while the education sector appears in low positions. Nevertheless, the Greek health care services and providers sector appears to have better rates than the international average, which positions the relevant international sector among those with the lowest levels of digital strategy clarity and employees' digital training. On the other hand, even though the Greek tourism sector would be expected to be digitally advanced - given its importance in the Greek economy - it seems to have medium to lower rates compared to international firms from the industry, which reveals its lack of a clear digital strategy, as reported to be the most serious of its problems by responders.

Furthermore, this study was subject to several limitations. The time available in order for this study to be conducted was rather limited due to the duration of the dissertation schedule at the Hellenic Open University (HOU) within which this study was conducted. A study conducted over a longer period would be better able to include a larger number of participants, offering reliable results even on topics and questions whose answers and data were limited. Moreover, this study only included answers from the participants' viewpoint. More results could be extracted from the real financial data of companies and the allocation of resources. Interviews from business executives and managers could also add important information about the reasoning, selection, design, and implementation of each digital strategy or its lack and allow for the collection of specific examples. 
Table 3. Summary of the main differences between business sectors

\begin{tabular}{|c|c|c|c|c|c|}
\hline Business Sector & $\begin{array}{c}\text { Sector's } \\
\text { average } \\
\text { digital } \\
\text { maturity }\end{array}$ & $\begin{array}{c}\text { Clear digital } \\
\text { strategy }\end{array}$ & $\begin{array}{l}\text { Digital } \\
\text { technologies can } \\
\text { transform the way } \\
\text { people work }\end{array}$ & $\begin{array}{l}\text { Digital skills } \\
\text { development }\end{array}$ & $\begin{array}{l}\text { Digitally } \\
\text { skilled } \\
\text { leaders }\end{array}$ \\
\hline Clothing & 3.00 & $0 \%$ & $50 \%$ & $0 \%$ & $0 \%$ \\
\hline Energy & 4.00 & $0 \%$ & $0 \%$ & $100 \%$ & $100 \%$ \\
\hline Professional Services & 4.12 & $41 \%$ & $76 \%$ & $47 \%$ & $47 \%$ \\
\hline Education & 4.50 & $0 \%$ & $50 \%$ & $25 \%$ & $0 \%$ \\
\hline $\begin{array}{l}\text { Industry / } \\
\text { Manufacturing }\end{array}$ & 4.70 & $40 \%$ & $63 \%$ & $60 \%$ & $58 \%$ \\
\hline Tourism & 5.44 & $33 \%$ & $67 \%$ & $56 \%$ & $56 \%$ \\
\hline Retail & 5.67 & $47 \%$ & $93 \%$ & $60 \%$ & $53 \%$ \\
\hline $\begin{array}{l}\text { Entertainment, Media } \\
\text { and Publications }\end{array}$ & 5.71 & $43 \%$ & $100 \%$ & $57 \%$ & $71 \%$ \\
\hline $\begin{array}{l}\text { Economic/Financial / } \\
\text { Bank Services }\end{array}$ & 6.40 & $20 \%$ & $80 \%$ & $80 \%$ & $60 \%$ \\
\hline $\begin{array}{l}\text { Health Care Services } \\
\text { \& providers }\end{array}$ & 7.00 & $67 \%$ & $33 \%$ & $67 \%$ & $50 \%$ \\
\hline Telecommunications & 7.50 & $100 \%$ & $100 \%$ & $100 \%$ & $100 \%$ \\
\hline IT Services & 8.00 & $71 \%$ & $86 \%$ & $100 \%$ & $86 \%$ \\
\hline
\end{tabular}

Source: own elaboration.

Finally, future research should include the ways in which digital transformation could help Greek companies continue their business during such periods as the global Covid-19 pandemic, which forced many governments worldwide to impose strict lockdowns while driving people to a more digitalized lifestyle in almost every aspect of their everyday life from work and shopping through communications to entertainment. Such a study should focus on the impact of the lockdowns on the digital transformation of Greek businesses and on the responses selected by the businesses that belong to different digital maturity levels, along with their objectives, limitations, barriers, and final achievements. 


\section{References}

Azhari, P., Faraby, N., Rossmann, A., Steimel, B. and Wichmann, K.S. (2014). Digital transformation report. Köln: neuland GmbH \& Co. KG.

Bucy, M., Finlayson, A, Kelly, G. and Moye, C. (2016). The 'how' of transformation. McKinsey \& Company. Available at:

https://www.mckinsey.com/industries/retail/our-insights/the-how-of-transformation.

Bughin, J., Hazan, E., Labaye, E., Manyika, J., Dahlström, P., Ramaswamy, S. and Cochin de Billy, C. (2016). Digital Europe: Pushing the Frontier, Capturing the Benefits. McKinsey \& Company, McKinsey Global Institute. Available from:

https://www.mckinsey.com/business-functions/mckinsey-digital/our-insights/digital-europe-realizing-the-continents-potential.

Bughin, J., Catlin, T., Hirt, M. and Willmott, P. (2018). Why digital strategies fail. McKinsey Quarterly. Available at:

https://www.mckinsey.com/business-functions/mckinsey-digital/our-insights/why-digital-strategies-fail.

Catlin, T., Scanlan, J. and Willmott, P. (2015). Raising your Digital Quotient. McKinsey Quarterly. McKinsey \& Company. Available at:

http://www.mckinsey.com/business-functions/strategy-and-corporate-finance/our-insights/ raising-your-digital-quotien.

Cearley, D., Jones, N., Smith, D., Burke, B., Chandrasekaran, A., and Lu, C.K. (2019). Top 10 Strategic Technology Trends for 2020. Gartner Research. Available at:

https://www.gartner.com/en/doc/432920-top-10-strategic-technology-trends-for-2020.

Desmet, D., Duncan, E., Scanlan, J. and Singer, M. (2015). Six building blocks for creating a high-performing digital enterprise. McKinsey \& Company. Available at:

https:/www.mckinsey.com/business-functions/organization/our-insights/six-building-blocks-for-creating-a-high-performing-digital-enterprise.

European Commission (2019). Digital Economy and Society Index (DESI). Country Report, Greece. https://ec.europa.eu/digital-single-market/en/scoreboard/greece.

European Commission (2015). The revised user guide to the SME definition. Available at:

https://ec.europa.eu/growth/content/revised-user-guide-sme-definition-0_en, \& https://eur-lex. europa.eu/legal-content/EN/TXT/HTML/?uri=LEGISSUM:n26026\&from=EL, https://ec.europa. eu/growth/smes/business-friendly-environment/sme-definition/.

Eurostat. Unemployment statistics, Youth unemployment. Available at:

https://ec.europa.eu/eurostat/statistics-explained/index.php/Unemployment_statistics\#Youth_ unemployment.

Fitzgerald, M., Kruschwitz, N., Bonnet, D. and Welch, M. (2014). Embracing Digital Technology - A New Strategic Imperative. MIT Sloan Management Review, 55(2), 1-12.

Gartner (2017). Press Releases: Gartner Survey Shows 42 Percent of CEOs Have Begun Digital Business Transformation. Gartner, Inc. Available at:

https://www.gartner.com/en/newsroom/press-releases/2017-04-24-gartner-survey-shows-42percent-of-ceos-have-begun-digital-business-transformation.

Granholm-Brun, A. and Berkman, R. (2013). Turning a "No Comment" Company into a Social Media Advocate. MIT Sloan Management Review. Available at:

https://sloanreview.mit.edu/article/turning-a-no-comment-company-into-a-social-media-advocate/

Hess, T., Christian Matt, C., Benlian, A. and Wiesböck, F. (2016). Options for Formulating a Digital Transformation Strategy. MIS Quarterly Executive, 15(2), 123-139. 
IDG.COM (2018). State of Digital Business Transformation: 2018. Executive Summary, IDG. Available at: https://www.idg.com/tools-for-marketers/2018-state-of-digital-business-transformation-whitepaper/.

Ismail, M.H., Khater, M. and Zaki, M. (2017). Digital Business Transformation and Strategy: What do we know so far? University of Cambridge, Cambridge Service Alliance. November 2017. https://doi.org/10.13140/RG.2.2.36492.62086.

Kane, G.C. Palmer, P., Phillips, A.N., Kiron, D. and Buckley, N. (2015). Strategy, Not Technology, Drives Digital Transformation. MIT Sloan Management Review, 14, 1-25.

Kaufman, I. and Horton, C. (2015). Digital Transformation: Leveraging Digital Technology with Core Values to Achieve Sustainable Business Goals. The European Financial Review, December-January, 63-67.

Kohli, R. and Johnson, S. (2011). Digital Transformation in Latecomer Industries: CIO and CEO leadership lessons from Enacana Oil \& Gas (USA) Inc. MIS Quarterly Executive, 10(4), 142-156.

Manyika, J., Ramaswamy, S., Khanna, S., Sarrazin, H., Pinkus, G., Sethupathy, G. and Yaffe, A. (2015). Digital America: A Tale of the Have and Have-More. McKinsey \& Company, McKinsey Global Institute. Available at: https://www.mckinsey.com/industries/technology-media-and-telecommunications/our-insights/digital-america-a-tale-of-the-haves-and-have-mores.

Matt, C., Hess, T. and Benlian, A. (2015). Digital Transformation Strategies. Business \& Information Systems Engineering, 57, 339-343. https://doi.org/10.1007/s12599-015-0401-5.

Porter, M.E. and Heppelmann, J.E. (2017). Why Every Organization Needs an Augmented Reality Strategy. Harvard Business Review, November, 46-62.

Reinsel, D., Gantz, J. and Rydning, J. (2018). The Digitization of the World - From Edge to Core. Executive Summary. IDC \& Seagate, November 2018. Available at:

https://www.seagate.com/files/www-content/our-story/trends/files/idc-seagate-dataage-whitepaper.pdf.

Sebastian, I.M., Ross, J., Beath, C., Mocker, M., Moloney, K. and Fonstad, N. (2017). How Big Old Companies Navigate Digital Transformation. MIS Quarterly Executive, 16(3), 197-213.

Singh, A., Hess, T. (2017). How Chief Digital Officers Promote the Digital Transformation of their Companies. MIS Quarterly Executive, 16(1), 1-17.

Skift (2017). The 2018 Digital Transformation Report - Skift powered by Abode: 15.11.2017. Available at: https://skift.com/insight/2018-digital-transformation-report/.

Stanton Chase (2017). Executive Newswire 2017 - Digital Transformation. ShantonChase.com: September 2017, 1-32. Available at:

https://stantonchase.com/athens/newswire-17/pdf/ExecutiveNewswire-17.pdf.

Tabrizi, B., Lam, E., Girard, K. and Irvin, V. (2019). Digital Transformation Is Not About Technology. Harvard Business Review, 3 March 2019.

Venkatraman, V. (2017). The Digital Matrix: New Rules for Business Transformation Through Technology Hardcover. Life Tree Media, 367.

Von Leipzig, T., Gamp, M., Manz, D., Schottle, K., Ohlhausen, P., Oosthuizen, G., Palm, D. and Von Leipzig, K. (2017). Initializing customer-orientated digital transformation in enterprises. Procedia Manufacturing, 8, 517-524. https://doi.org/10.1016/j.promfg.2017.02.066.

Westerman, G., Bonnet, D. and Mcafee, A. (2014). The Nine Elements of Digital Transformation. MIT Sloan Management Review, 55(3), 1-6.

Westerman, G., Bonnet, D. and McAfee, A. (2014). Leading digital: Turning technology into business transformation. Boston: Harvard Business Review Press. 
Westermann, G., Tannou, M., Bonnet, D., Ferraris, P. and McAfee, A. (2012). The Digital Advantage: How digital leaders outperform their peers in every industry. MIT Sloan Management \& Capgemini Consulting, 1-24. Available at:

https://www.capgemini.com/wp-content/uploads/2017/07/The_Digital_Advantage_How_Digital_Leaders_Outperform_their_Peers_in_Every_Industry.pdf.

Westerman, G., Calméjane, C., Bonnet, D., Ferraris, P. and McAfee, A. (2011). Digital Transformation: A Roadmap for Billion-Dollar Organizations. MIT Center for Digital Business and Capgemini Consulting, 1-68. Available at:

https://www.capgemini.com/wp-content/uploads/2017/07/Digital_Transformation_A_RoadMap_for_Billion-Dollar_Organizations.pdf.

White, M. (2012). Digital workplaces: Vision and reality. Business Information Review, 29(4), 205-214. https://doi.org/10.1177/0266382112470412.

ZoBell, S. (2018). Why Digital Transformations Fail: Closing The \$900 Billion Hole In Enterprise Strategy. Forbes.com. Available at:

https://www.forbes.com/sites/forbestechcouncil/2018/03/13/why-digital-transformations-fail-closing-the-900-billion-hole-in-enterprise-strategy/\#5e9ac3157b8b. 